\title{
Near real time water quality monitoring of Chivero and Manyame lakes of Zimbabwe
}

\author{
Ronald Muchini ${ }^{1}$, Webster Gumindoga ${ }^{2}$, Sydney Togarepi ${ }^{1}$, Tarirai Pinias Masarira ${ }^{2}$, and \\ Timothy Dube ${ }^{3}$ \\ ${ }^{1}$ University of Zimbabwe, Dept. of Geoinformatics and Surveying, \\ Box MP 167, Mt Pleasant Harare, Zimbabwe \\ ${ }^{2}$ University of Zimbabwe, Dept. of Civil Engineering, Box MP 167, Mt Pleasant, Harare, Zimbabwe \\ ${ }^{3}$ Dept. of Earth Sciences, University of the Western Cape, Private Bag X17, Bellville, South Africa \\ Correspondence: Webster Gumindoga (wgumindoga@gmail.com)
}

Received: 16 November 2017 - Revised: 22 February 2018 - Accepted: 2 March 2018 - Published: 29 May 2018

\begin{abstract}
Zimbabwe's water resources are under pressure from both point and non-point sources of pollution hence the need for regular and synoptic assessment. In-situ and laboratory based methods of water quality monitoring are point based and do not provide a synoptic coverage of the lakes. This paper presents novel methods for retrieving water quality parameters in Chivero and Manyame lakes, Zimbabwe, from remotely sensed imagery. Remotely sensed derived water quality parameters are further validated using in-situ data. It also presents an application for automated retrieval of those parameters developed in VB6, as well as a web portal for disseminating the water quality information to relevant stakeholders. The web portal is developed, using Geoserver, open layers and HTML. Results show the spatial variation of water quality and an automated remote sensing and GIS system with a web front end to disseminate water quality information.
\end{abstract}

\section{Introduction}

Harare the capital city of Zimbabwe and its satellite towns (commonly known as Greater Harare) are seated in the Upper Manyame sub-catchment that supplies its water resources. Chivero and Manyame Lakes are the major sources of water for Greater Harare which are also situated downstream of the sub-catchment. It follows that any land use related activity in the Upper Manyame sub-catchment will affect the water status of the lakes. The Lakes are now rated among Zimbabwe and the world's most polluted inland water bodies (Chigonda, 2011; Chawira et al., 2013) and Chivero is rated among the world's most polluted lakes (Herald, 2012). The leading sources of pollution in these lakes have been identified by Kibena et al. (2013) as sewage (raw or partially treated) from sewer treatment plants as well as urban runoff. According to Buka et al. (2014), all the major sewage treating plants have been releasing their effluent into the local river system. Industries release their waste effluent into the river system. Leaching of nutrients from urban agricultural activities is also affecting the nutrient content of the lakes. Masere et al. (2012) and Kibena et al. (2013) supports the fact that the water quality of Upper Manyame has been impaired over the years.

A massive rise in urban population was realized over the past years (20-34\% between 1992 and 2002) and this hasled to the population overriding the urban utilities, hence the release of raw sewer into water bodies (Mapira, 2011). The deteriorating water quality is having adverse health effects on the populace, as well as leading to high water treating costs (Mlambo, 2013). The cholera outbreaks in Zimbabwe of 2002 and 2008 which affected about 11735 lives with 484 deaths are attributed to poor sanitation and provision of polluted water to residents (Buka et al., 2014). Such deadly impacts of water pollution on humanity makes it of paramount importance to perform regular and synoptic water quality assessment and monitoring in the above-mentioned water bodies.

Water quality monitoring involves the retrieval of water quality parameters from the water for water management purposes (Dept. of Ecology State of Washington, 2012; 
EMA, 2014). The current methods of water quality monitoring in Zimbabwe involves only the use of in-situ and laboratory based methods (EMA, 2012). These methods are costly, tedious, time consuming and do not provide complete spatial coverage of the water bodies and the water quality parameters of concern. This leaves the nation and the responsible authorities in particular with no option but to find and implement more efficient integrated water response strategies.

The applicability of remote sensing in retrieval of water quality variables, use of programming in automating GIS and remote sensing tasks and sharing of GIS products over the world wide web network allows for the development of an integrated and automated system for monitoring water quality and disseminating the results in near real time.

In this study we develop a near real-time water quality monitoring system for Chivero and Manyame lakes of Zimbabwe. This is achieved through identifying suitable algorithms that can determine water quality parameters and develop an application, which computes water quality parameters and present them on a web GIS.

\section{Materials and methods}

\subsection{Study area}

Chivero and Manyame Lakes are situated in the Upper Manyame sub-catchment of Zimbabwe which also contains the Greater Harare. The Surface area for Chivero and Manyame is about 26.3 and $81 \mathrm{~km}^{2}$ (ZRA, 1998). The lakes are located at a lower altitude than most areas of the catchment including the city and all of its residential areas and industries. Rainfall received in the sub-catchment is nearly $798.6 \mathrm{~mm} \mathrm{yr}^{-1}$. Surface runoff especially during the wet season will always carry pollutants to the lakes. Lake Chivero has been hypertrophic since the 1960s and Manyame is now showing evidence of being hypertrophic as well (Magadza, 2008; Dlamini, 2012). The two lakes are currently Greater Harare's main source of water hence the need for them to be closely monitored.

\subsection{Data availability}

Remote sensing and field based (in-situ) data were applied. Field based water quality data was obtained from in situ measurements for Chivero at three selected sampling points by Dlamini (2012). Landsat 5-7 Thematic Mapper (TM) and Enhanced Thematic Mapper (ETM+), freely available from the United States Geological Survey (USGS) website were used for this research. The imagery has a $30 \mathrm{~m}$ and 16 day spatial and temporal resolution respectively. Only imagery with less than $30 \%$ cloud cover was selected for use.

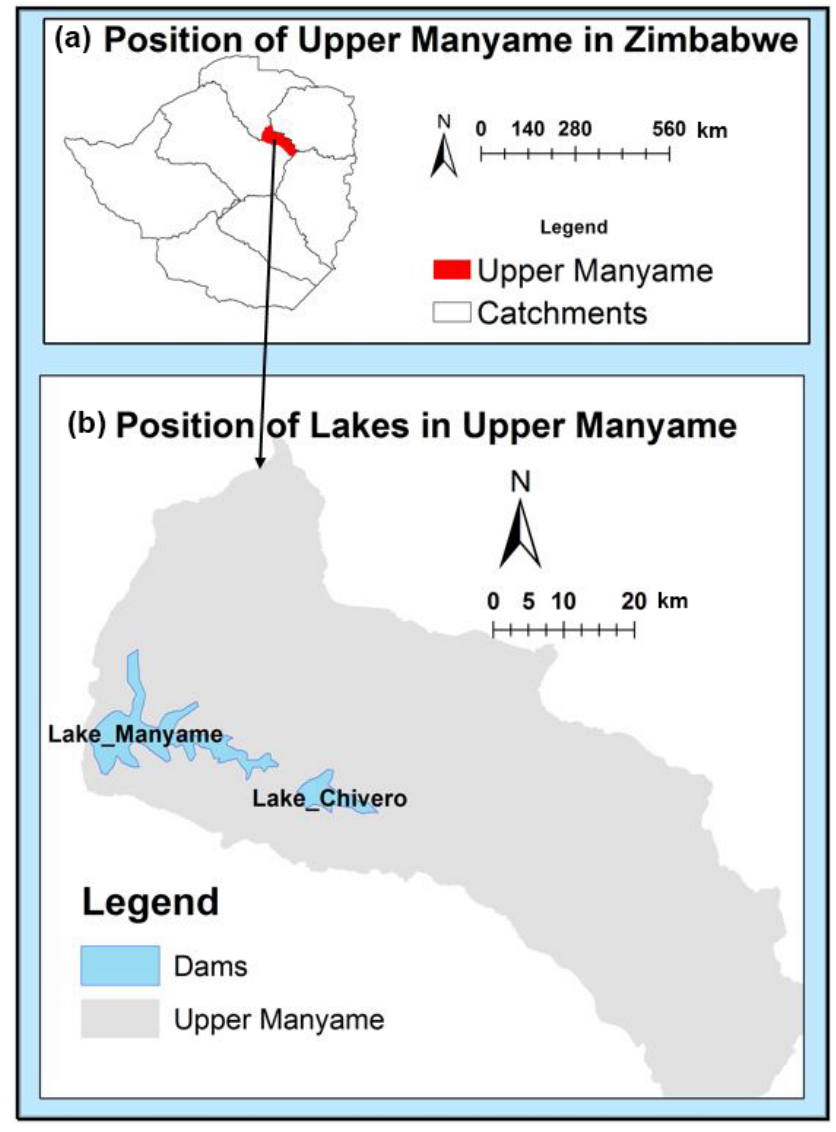

Figure 1. Map of study area (first: Upper Manyame in Zimbabwe, second: Lakes Chivero and Manyame in Upper Manyame).

\subsection{Determination of water quality parameters}

Landsat Imagery was downloaded for April and September (1986, 1990, 2000, 2005, 2012 and 2015) from the USGS glovis website. Image preprocessing was done through the conversion from Digital Numbers (DN) to spectral radiance by implementing the Chander et al. (2009) algorithm using the ENvironment for Visualizing Images (ENVI) software. The water quality parameters were computed in ILWIS. The computed raster maps were resampled to a common georefrence and the lake are extracted. The water quality parameters were validated using the point to pixel method (Chander et al., 2009).

The authors used formulae in Shafique et al. (2002) and Dlamini (2012) as shown in Table 1. Several formulas applied before in tropical lakes have been tested and it is the formula from the above authors that yielded better correlation with ground based measurements and thus has been adopted in this study. 


\subsection{Application for automated retrieval of water quality parameters}

ILWIS software was used for automating retrieval.Making use of of ILWIS's DDE server capabilities and VB6's DDE client capabilities, the automation of water quality parameters computation was achieved using VB6. A client program to ILWIS was programmed in VB6 also using ILWIS scripting commands (ILWIS, 2013; Microsoft, 2015). The application provides navigation tools for the user to navigate through the host computer and and to select the folder containing the images and click a command button so that the automated computations begin.

\subsection{Dissemination of water quality data via the web}

Geoserver was installed and the necessary set up done. The web interface and client to the data was programmed using HTML, JavaScript and PHP scripting languages, as well as the OpenLayers mapping library. It was designed in such a way to allow the user to enter date and parameter of interest, and then the program would retrieve the specified parameter at the specified date and present it as a map.

\section{Results and discussion}

\subsection{The spatial variation of water quality parameters}

The research presents four successfully determined water quality parameters; Chlorophyll $a$, turbidity, totals Phosphorus and Total Suspended Matter. Figures 2-5 show the spatial and temporal variations of the water quality parameters. The parameter values from 0 to a maximum are represented on the maps with colour variations from blue to red with interpolation in between.

\subsubsection{Chlorophyll a (Chl a)}

The minimum value for Chl $a$ was $0.00 \mathrm{mug} \mathrm{L}^{-1}$ for all years whilst the maximum varied between 0.15 and 0.23 mug $\mathrm{L}^{-1}$ without any particular order of change. However, an increase in the amount of Chl $a$ can be noted by the increase in the redness of the map. There is a notable increase in the pollution with respect to $\mathrm{Chl} a$ over time with the 2005 being an exemption in the trend due to its extremely low values as shown by the blue color intensity. Figure 2 shows the trends explained here. The values 0.15 to $0.23 \mathrm{mug} \mathrm{L}^{-1}$ show a hypertrophic lake and therefore agree with Nhapi (2008) who reiterated that lake Chivero has been eutrophic since 1960 when the first algal blooms appeared. Dlamini (2012) also got values $0.101 \pm 0.128 \mathrm{mug} \mathrm{L}^{-1}$ which basically falls in the same range as given in this work.

\subsubsection{Turbidity $(\mathrm{Tb})$}

There is a general increase in the pollution levels with respect to turbidity as it is evident on the diagrams by the increase in the intensity of red on the maps. The year 1995 is noted as an exception in the trend. Generally, the minimum value of the parameter increased from 1.2 NTU in 1986 to $3.6 \mathrm{NTU}$ in 2015, whilst the maximum parameter value increased from 3.2 to $5.8 \mathrm{NTU}$ throughout the study period. The spatial and temporal variations of turbidity are shown on Fig. 3. Turbidity values of less than 5 NTU are accepted by the Zimbabwean effluent standards. So, the water quality changed from an acceptable status of 3.2 to $5.8 \mathrm{NTU}$ a status beyond the accepted.

\subsubsection{Total Phosphorus (TP)}

The minimum values of total phosphorus varied from 0.00 to $0.91 \mathrm{mg} \mathrm{L}^{-1}$ from 1986 to 2015 . In the same vein, the maximum total phosphorus varied from 0.04 to $6.82 \mathrm{mg} \mathrm{L}^{-1}$. This variation shows that the water quality (with respect to TP) has been deteriorating with time from 1986. This could probably be due to increasing Harare population and therefore increased use of fertilizers in urban agriculture which would leach into the water system. Generally, the mean values shows a hypertrophic lake with respect to TP and this is in sync with the work of Nhapi (2008) who postulated that the lakes were eutrophic since 1960. Dlamini (2012) also found the lake hypertrophic at $1.17 \mathrm{mg} \mathrm{L}^{-1}$. Figure 4 shows the spatial and temporal variations of TP.

\subsubsection{Total Suspended Matter (TSM)}

Figure 5 shows the spatial and temporal variation of TSM. The variations of water pollution status with respect to TSM were actually retrogressive in that from 1986 to 2015 the maximum and minimum values varied from 3.25 to $1.77 \mathrm{mug} \mathrm{L}^{-1}$ and 0.39 to $0.37 \mathrm{mug} \mathrm{L}^{-1}$ respectively. However, the retrogression was not gradual, an increase is noted from 1995 to 2005 on the maximum values as well as a slight increase to 2015. The decrease is probably explained by the growth of weeds and other forms of vegetation along the edges of the lakes such that the suspended solids heading for the water are trapped in the weeds before reaching the water itself.

\subsubsection{Summary of all retrieved parameters}

Table 2 is a summary of the water quality parameters, showing the maximum and minimum of each parameter from 1986 to 2015 . The parameters show that the lake is polluted and pollution generally increased with time. 
Table 1. Algorithms for retrieval of water quality parameters from Landsat images.

\begin{tabular}{llll}
\hline Parameter & Algorithm i.d & Algorithm & Units \\
\hline Chlorophyl $a$ & $3.4 .1 \ldots$ & $\begin{array}{l}\mathrm{Chl} a=(486 \cdot \mathrm{NDVI}+44) \cdot-0.001 \\
\mathrm{NDVI}=(\mathrm{B} 4-\mathrm{B} 3) /(\mathrm{B} 4+\mathrm{B} 3)\end{array}$ & $\mu \mathrm{gL}^{-1}$ \\
\hline Turbidity & $3.4 .2 \ldots$ & $\mathrm{Tb}=5.0819 \cdot\left(\frac{\mathrm{B} 1}{\mathrm{~B} 3}\right)^{-1.0125}$ & $\mathrm{NTU}$ \\
\hline Total Phosphorus & $3.4 .3 \ldots$ & $\mathrm{Ln}(\mathrm{TP})=4.334-4.594\left(\frac{\mathrm{B} 1}{\mathrm{~B} 2}\right)+1.103\left(\frac{\mathrm{B} 4}{\mathrm{~B} 7}\right)$ & $\mathrm{mgL}^{-1}$ \\
\hline Total Suspended Matter & $3.4 .4 \ldots$ & $\mathrm{TSM}=3.39 \cdot\left(\frac{\mathrm{B} 2}{\mathrm{~B} 3}\right)-2.6$ & $\mu \mathrm{gL}^{-1}$ \\
\hline
\end{tabular}

(Shafique et al., 2002; Dlamini, 2012)

NB B1-B7 refers to Band 1 to Band 7 of Landsat TM/ETM+ in all equations in Table 1.

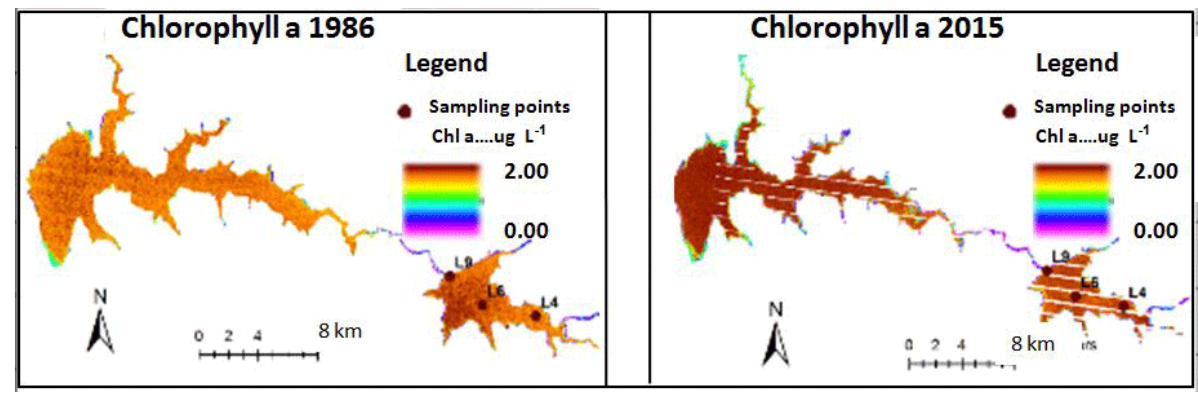

Figure 2. Spatial variations of Chlorophyll $a 1986$ and 2015.

Table 2. Summary of the estimated water quality variables.

\begin{tabular}{|c|c|c|c|c|c|}
\hline Date & Parameter & Min & Mean & Max & Units \\
\hline \multirow[t]{4}{*}{31 Aug 1986} & Chl $a$ & 0.0000 & 0.040 & 0.2184 & $\operatorname{mug} L^{-1}$ \\
\hline & Turbidity & 1.2486 & 1.590 & 3.2739 & NTU \\
\hline & $\mathrm{TP}$ & 0.0000 & 1.590 & 22726 & $\mathrm{mgL}^{-1}$ \\
\hline & TSM & 0.0000 & 1.580 & 20.246 & $\operatorname{mug} L^{-1}$ \\
\hline \multirow[t]{4}{*}{10 Aug 1990} & Chl $a$ & 0.0000 & 0.010 & 0.1698 & $\operatorname{mug} L^{-1}$ \\
\hline & Turbidity & 0.9764 & 1.390 & 3.5554 & NTU \\
\hline & TP & 0.0001 & 0.010 & 13.527 & $\mathrm{mgL}^{-1}$ \\
\hline & TSM & 0.0000 & 1.940 & 4.1800 & $\operatorname{mug} L^{-1}$ \\
\hline \multirow[t]{4}{*}{8 Aug 1995} & Chl $a$ & 0.0000 & 0.001 & 0.2330 & $\operatorname{mug} L^{-1}$ \\
\hline & Turbidity & 1.2756 & 2.670 & 4.6672 & NTU \\
\hline & $\mathrm{TP}$ & 0.0005 & 0.551 & 411319 & $\mathrm{mgL}^{-1}$ \\
\hline & TSM & 0.0000 & 0.520 & 2.4850 & $\operatorname{mug} L^{-1}$ \\
\hline \multirow[t]{4}{*}{13 Aug 2000} & Chl $a$ & 0.0000 & 0.040 & 0.1552 & $\operatorname{mug} L^{-1}$ \\
\hline & Turbidity & 1.9733 & 3.310 & 5.9002 & NTU \\
\hline & TP & 0.0614 & 1.510 & 494.10 & $\mathrm{mgL}^{-1}$ \\
\hline & TSM & 0.0000 & 1.370 & 2.7932 & $\operatorname{mug} L^{-1}$ \\
\hline \multirow[t]{4}{*}{4 Sep 2005} & Chl $a$ & 0.0000 & 0.002 & 0.1164 & $\operatorname{mug} L^{-1}$ \\
\hline & Turbidity & 1.5518 & 2.050 & 3.6652 & NTU \\
\hline & TP & 0.0011 & 0.020 & 6.4145 & $\mathrm{mgL}^{-1}$ \\
\hline & TSM & 0.0000 & 0.920 & 1.7145 & $\operatorname{mug} L^{-1}$ \\
\hline \multirow[t]{4}{*}{19 Jan 2015} & Chl $a$ & 0.0000 & 0.100 & 0.2135 & $\operatorname{mug} L^{-1}$ \\
\hline & Turbidity & 3. 6161 & 4.400 & 5.8373 & NTU \\
\hline & $\mathrm{TP}$ & 0.9099 & 4.120 & 187.82 & $\mathrm{mgL}^{-1}$ \\
\hline & TSM & 0.3704 & 1.360 & 1.7673 & $\operatorname{mug} L^{-1}$ \\
\hline
\end{tabular}

Table 3. Validation of Chlorophyll $a$.

\begin{tabular}{lrr}
\hline Sampling Point & $\begin{array}{r}\text { Remotely sensed } \\
\text { Chl } a\left(\mathrm{mug} \mathrm{L}^{-1}\right)\end{array}$ & $\begin{array}{r}\text { In-situ measured } \\
\text { Chl } a\left(\mathrm{mug} \mathrm{L}^{-1}\right)\end{array}$ \\
\hline L4 & 0.180 & 0.201 \\
L6 & 0.140 & 0.160 \\
L9 & 0.126 & 0.144 \\
\hline
\end{tabular}

\subsubsection{Validation of retrieved parameters}

Using data obtained from Dlamini (2012) and February 2012 Landsat imagery, the remotely sensed parameters were compared to in-situ derived data from three lake sampling points which are L4, L6, and L9.

\section{Chlorophyll a}

The remotely sensed remote sensing values for the four sites show a deviation of $0.021,0.02$ and $0.018 \mathrm{mug} \mathrm{L}^{-1}$ for the sites L4, L6, and L9 respectively. So, on average, the remotely sensed data has about $-0.02 \mathrm{mug} \mathrm{L}^{-1}$ deviation from the in situ-derived values. Table 3 shows the relationship between remotely sensed Chl $a$ and In-situ derived Chl $a$. 


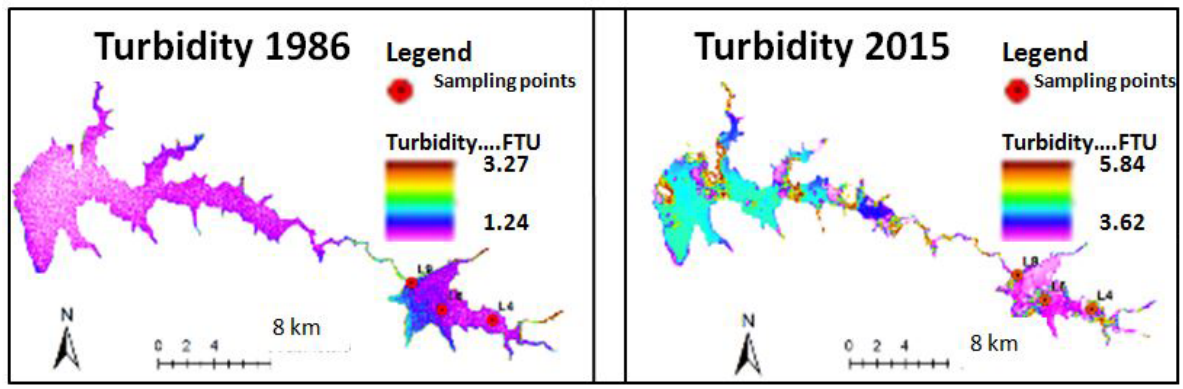

Figure 3. Spatial variations of Turbidity 1986 and 2015.

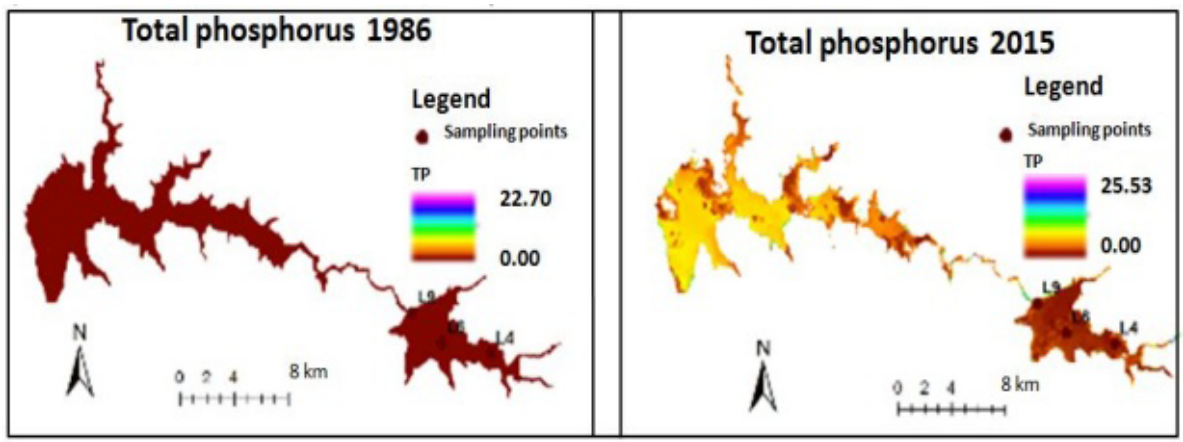

Figure 4. Spatial variations of Total Phosphorus 1986 and 2015.

Table 4. Validation of total phosphorus.

\begin{tabular}{lrr}
\hline Sampling Point & $\begin{array}{r}\text { Remotely sensed } \\
\mathrm{TP}\left(\mathrm{mg} \mathrm{L}^{-1}\right)\end{array}$ & $\begin{array}{r}\text { In-situ measured } \\
\mathrm{TP}\left(\mathrm{mg} \mathrm{L}^{-1}\right)\end{array}$ \\
\hline L4 & 0.337 & 0.880 \\
L6 & 0.972 & 1.500 \\
L9 & 0.600 & 1.130 \\
\hline
\end{tabular}

\section{Total phosphorus}

The remotely sensed values of total phosphorus show deviations of $0.543,0.528$ and 0.530 for L4, L6 and L9 site respectively. Hence an average of -0.53 deviation from the in-situ derived is observed for total phosphorus. Table 4 shows in situ derived TP and remotely sensed TP.

\subsection{Automation of water quality parameters' retrieval}

The determination of parameters was successfully automated, from the stage of importing them up to the finished water quality maps. This was achieved using the vb6 application with the interface shown on Fig. 6.It is the back-end application which the personnel responsible for water quality data dissemination will be using to retrieve water quality parameters from satellite imagery. The interface allows the user to navigate to a directory where a satellite image is stored and by clicking the locate button and then the proceed button that comes on top of the locate button in about $10 \mathrm{~s}$ after clicking the locate button. Kabo-bah (2010) also developed a water quality modelling scheme which was integrated with ILWIS. However, his system was installed as a plug in in ILWIS and therefore requiring the users to have knowledge of the software in to be able to manipulate it.

\subsection{The web dissemination of water quality data}

The dissemination of water quality data to the web was achieved using Geoserver accessing imagery in a file folder and OpenLayers. The client main webpage provides the user with three dropdown menus, the other one to select year, another month and the other one to select the parameter which the user wants to view. There is also a submit button which the user uses to submit their query to the host and retrieve the desired water quality parameter.

The buttons captioned "about us", "database" and "contact us" lead to the respective web pages as labelled.

Mouse location on the lakes is also shown by coordinates in WGS84 UTM, on the bottom right end of the map section. Steissberg et al. (2010) developed a web accessible repository similar to the one presented in this paper for Lake Tahoe, South Nevada. However, theirs allowed users to make downloads of the water quality products, functionality not provided for here. Another web GIS system comparable to this one was developed by Li et al. (2006), however this one was for exploration and visualisation of ice in Arctic waters. 


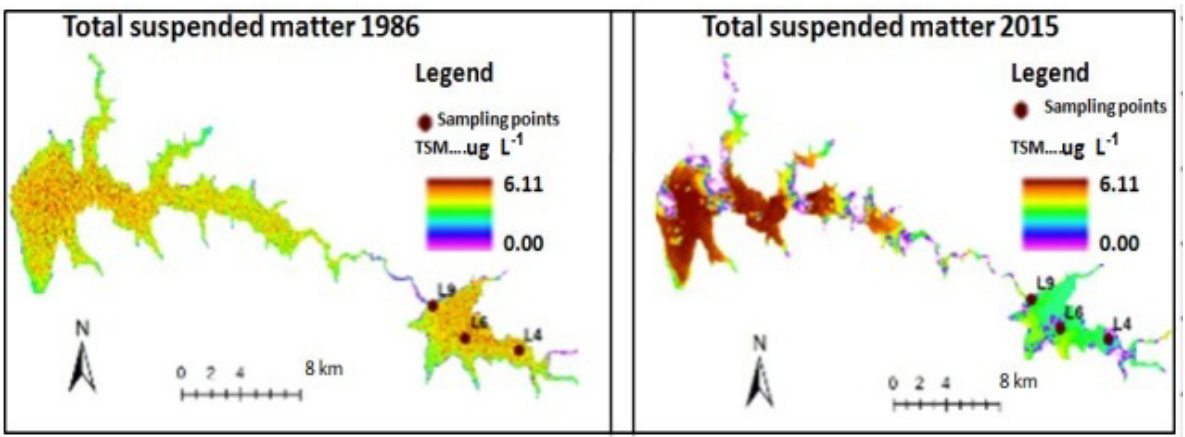

Figure 5. Spatial variations of Total Suspended Matter 1986 and 2015.

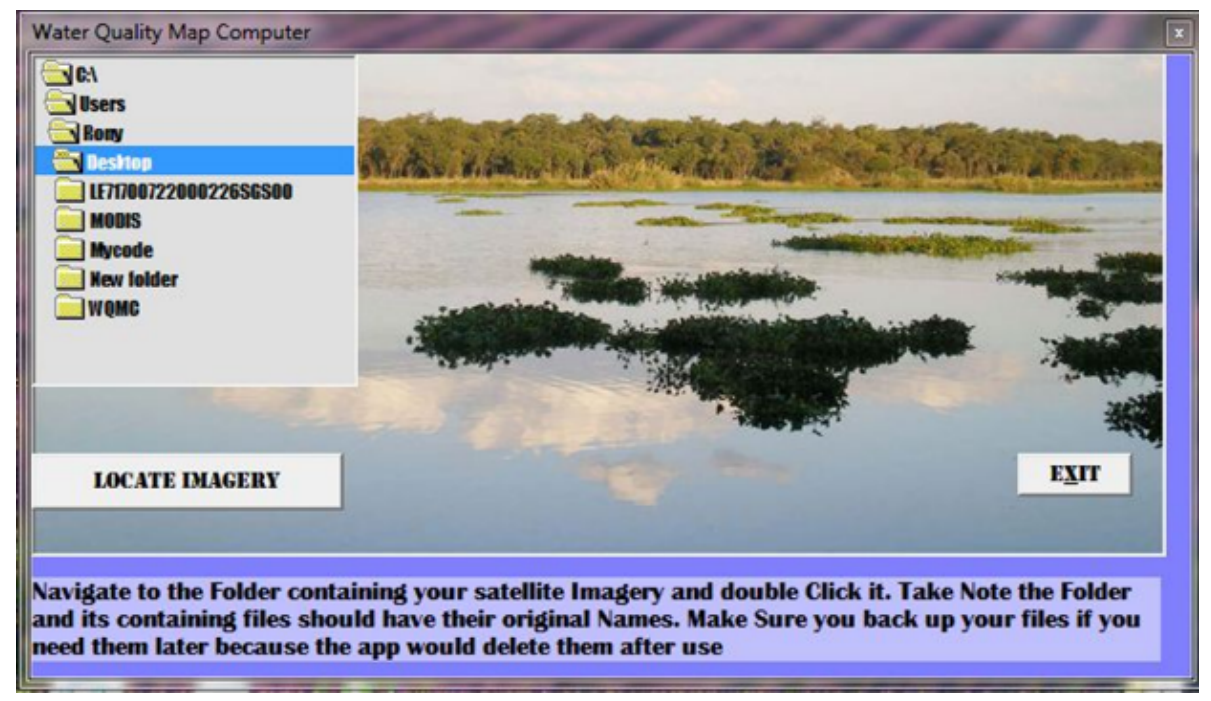

Figure 6. Interface of the backend application for automated remote sensing and GIS.

Stakeholders that could benefit from this system include the Environmental management Agency (EMA), Zimbabwe National Water Authority (ZINWA), the Upper Manyame sub-Catchment Council (UMSCC) and those responsible for pollution. ZINWA for decision making as they mainly deal with surface water abstraction. EMA and local authorities can use this to raise awareness to the public on how much their activities are affecting the environment for effective clean up and environmental campaigns.

\section{Conclusions}

Three conclusions were drawn.

1. Four water quality parameters were successfully determined that is Chlorophyll $a$, Turbidity, Total Phosphorus and Total Suspended Matter. These parameters are among the key indicators of water pollution and quality. Water quality of Chivero and Manyame lakes has been deteriorating that is specifically with respect to the determined water quality parameters in the study period.
2. The retrieval of water quality parameters can be automated by combining computer programming and remote sensing tools. In this work the determination of all the above-mentioned parameters were automated and the results from the automated process were found to be tallying with those obtained when the processes were executed manually. Water quality data can be made accessible to the public easily and on a near real time basis using web GIS technology.

3. There is therefore a need to apply remote sensing and GIS tools in water quality monitoring in order to reduce the costs of monitoring. This will also provide information of the spatial variations of the key water parameters and do away with the statistical assumptions of sampling. Spatial variations of water quality parameters can also put water treatment organizations in a better position by knowing lake areas for water withdrawal from at any given time and reduce treatment costs. The water quality parameter computing application eliminates human error in processing. 


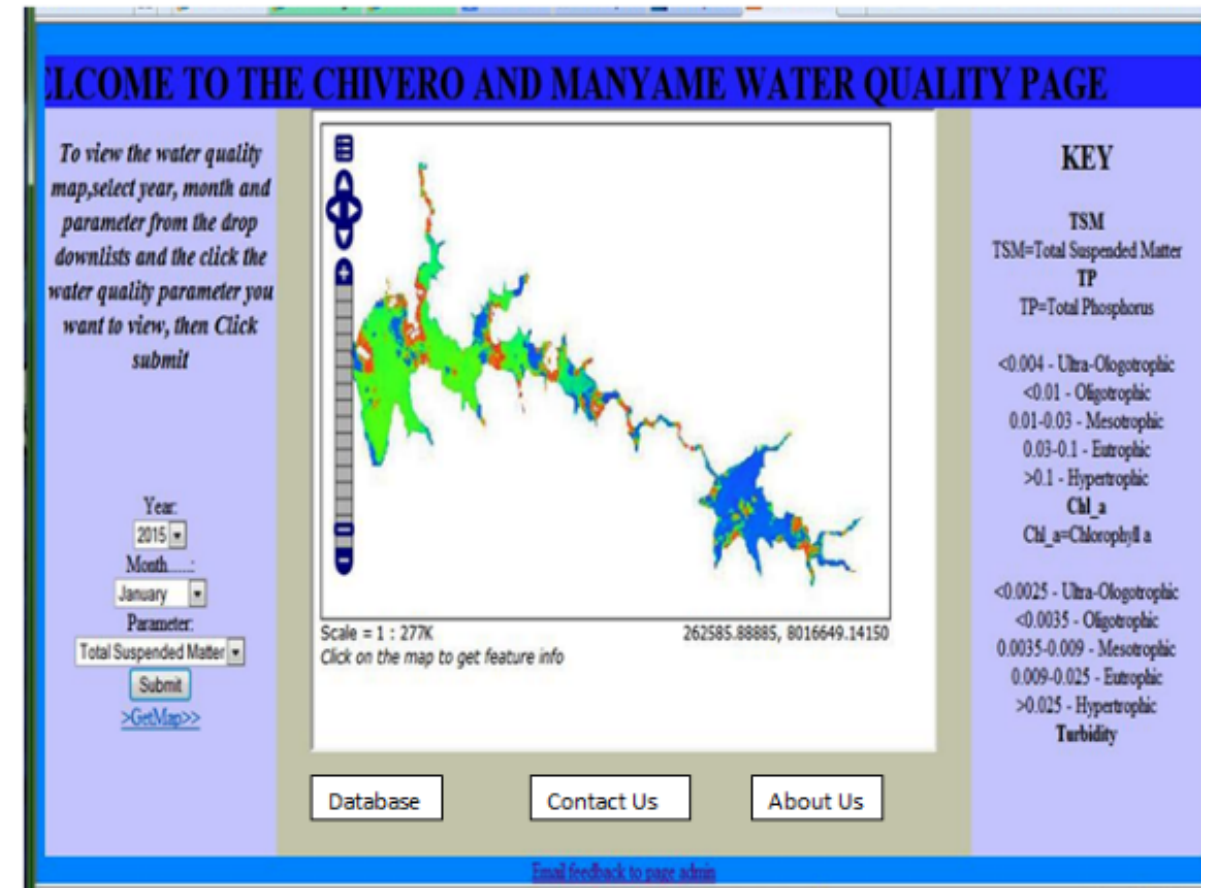

Figure 7. The web accessible interface to water quality data.

Data availability. Data may be accessed by emailing our first author.

Competing interests. The authors declare that they have no conflict of interest.

Special issue statement. This article is part of the special issue "Understanding spatio-temporal variability of water resources and the implications for IWRM in semi-arid eastern and southern Africa". It is a result of the IAHS Scientific Assembly 2017, Port Elizabeth, South Africa, 10-14 July 2017.

Edited by: Jean-Marie Kileshye-Onema

Reviewed by: Colleta Tundu and Nyaradzayi Mawango

\section{References}

Buka, H., Linhoss, A., and Pote, J.: An Integrated Watershed Approach to Water and Sanitation Hygiene priorities through a Narrative Review of Lake Chivero, Zimbabwe, Starkville, 2014.

Chander, G., Markham, B. L., and Helder, D. L.: Summary of Current Radiometric Calibration Coefficients for, Remote Sens. Environ., 1, 1-24, 2009.

Chawira, M., Dube, T., and Gumindoga, W.: Remote sensing based water quality monitoring in Chivero and Manyame lakes of Zimbabwe, Phys. Chem. Earth, 66, 38-44, https://doi.org/10.1016/j.pce.2013.09.003, 2013.
Chigonda, T.: Thirst in the midst of the Twin lakes: A quest for understanding Norton's ironical water woes, Journal of Sustainable Development in Africa, 13, 295-303, 2011.

Dept. of Ecology State of Washington: Water Quality Program Policy, USA, 2012.

Dlamini, S.: Evaluation Of The Water Quality Statusin Lake Chivero, Zimbabwe, University of Zimbabwe, 2012.

EMA.: Environmental Management Agency - Water testing services, available at: http://www.ema.co.zw/index.php/ 2014-06-1203-49-33/2014-06-12-03-50-38/ema-services/ 50-water-testing-services.html (last access: 22 April 2015), 2012.

EMA.: Ambient water quality monitoring, 2014, available at: http: //www.herald.co.zw/ambient-water-quality-monitoring/ (last access: 20 March 2015), 2014.

Herald: The Herald, Lake Chivero Ranks High in pollution, 18 April, Lake Chivero Ranks High in pollution, available at: https: //www.herald.co.zw/lake-chivero-ranks-high-in-pollution/ (last access: 10 March 2018), 2012.

ILWIS.: Apendices ILWIS as a DDE server(Adavanced). Available at: http://spatial-analyst.net/ILWIS/htm/ilwis/appendices_ilwis_ as_dde_server.htm (last access: 23 April 2015), 2013.

Kabo-bah, A.: Developing water quality modelling scheme in ILWIS Open for the Dinkel River in support of climate change and adaptation studies Developing water quality modelling scheme in ILWIS Open for the Dinkel River in support of climate change and adaptation studi, Twente, Enschede, 2010.

Kibena, J., Nhapi, I., and Gumindoga, W.: Assessing the relationship between water quality parameters and changes in landuse patterns in the Upper Manyame River, Zimbabwe, J. Phys. Chem. Earth, 67-60, 153-163, https://doi.org/10.1016/j.pce.2013.09.017, 2013. 
Li, S., Xiong, C., and Ou, Z.: Development Of Web-Based Ice Information System, Ou 2002, Canada, 2006.

Magadza, C. H.: Management of Eutrophication in Lake Chivero?, Success and failures?: A Case Study, Harare, 2008.

Mapira, J.: River pollution in the City of Mutare (Zimbabwe) and Its Implications For Sustainable Development, Journal of Sustainable Development in Africa, 13, 181-194, 2011.

Masere, T. P., Munodawafa, A., and Chitata, T.: Assessment of human impact on water quality along Manyame River, Int. J. Develop. Sustainability, 1, 754-765, 2012.

Microsoft: About Dynamic Data Exchange, available at: https://msdn.microsoft.com/en-us/library/windows/desktop/ ms648774(v=vs.85).aspx (last access: 23 March 2018), 2015.

Mlambo, M.: Zimbabwe's river system heavily polluted, available at: www.thestandard.co.zw/2013/04/07/ zimbabwes-river-system-heavily-polluted/ (last access: 17 February 2015), 2013.
Nhapi, I.: Inventory of water management practices in Harare, Zimbabwe, Water Environ. J., 22, 54-63, https://doi.org/10.1111/j.1747-6593.2007.00084.x, 2008.

Shafique, N. A., Fulk, F., Autrey, B. C., Flotemersch, J.: Hyperspectral Remote Sensing of Water Quality Parameters for Large Rivers in the Ohio River Basin, Environmental Protection Agency, USA, 2002.

Steissberg, T., Schladow, G., and Hook, S.: Monitoring past, present, and future water quality using remote sensing, Tahoe environmental research ..., Southern Nevada, 2010.

ZRA: Water Consumption and Effluent from Food and Agricultural Sector including Fisheries and Livestock, Danida, 1998. 